\title{
The Sidi Mohamed peridotites (Edough Massif, NE Algeria): Evidence for an upper mantle origin
}

\author{
SORAYA Hadj ZobIR ${ }^{1, *}$ and Roland OBERHÄNSLi ${ }^{2}$ \\ ${ }^{1}$ Laboratory of Soils and Sustainable Development, Badji Mokhtar-Annaba University, \\ P.O. Box 12, Annaba 23000, Algeria. \\ ${ }^{2}$ Department of Earth and Environmental Sciences, University of Potsdam, Karl-Liebknecht-Strasse 24-25, \\ Building 27, Potsdam-Golm 14476, Germany. \\ ${ }^{*}$ Corresponding author.e-mail: shadjzobir@yahoo.fr
}

The Hercynian Edough massif is the easternmost crystalline massif of the Algerian coast. It consists of two tectonically superposed units composed of micaschists, gneisses, and peridotite. This study concentrates on the small and isolated Sidi Mohamed peridotite outcrop area $\left(0.03 \mathrm{~km}^{2}\right)$. The Sidi Mohamed peridotite is composed mainly of harzburgites (Mg-rich olivine and orthopyroxene as major minerals). The Ni (2051-2920 ppm), Cr (2368-5514 ppm) and $\mathrm{MgO}$ ( 28-35 wt.\%) whole-rock composition and the relative depletion in $\mathrm{Nb}$ make these harzburgites comparable to depleted peridotites related to a subduction zone. We suggest that the Sidi Mohamed ultramafic body was derived directly from the upper mantle and tectonically incorporated into the gneiss units of the Edough metamorphic core complex in a subduction environment.

\section{Introduction}

Direct outcrop of peridotites on the ocean floor via denudation of the mantle occurs in different tectonic environments (Blackman et al. 1998; Kamenentsky et al. 2001). Slow-spreading midoceanic ridges produce an important extensional environment, where mantle rocks are exposed (Dick and Bullen 1984; Cannat 1993; Tucholke and Kleinrock 1998). In addition, mantle peridotites are found in a variety of geologic settings: as mantle sections in ophiolites, as peridotites representing the residue from melt extraction of the oceanic crust or as xenoliths in basaltic rocks. During the geological evolution of the Mediterranean Sea, fragments of the lithosphere were tectonically obducted on the North African margin. In north Algeria, there are several ultramafic outcrops that contain such mantle rocks. From west to east they are ultramafic xenolites of Oran (Zerka et al. 2002), the feldsphatic peridotites of Cape Bougaroune (Misseri 1983; Leblanc and Temagoult 1989), the Kef Lekhal (Voile Noire) peridotitic enclaves in amphibolites (Ahmed Said and Leake 1992, 1997) and the small ultramafic-mafic outcrop of Sidi Mohamed (Bossière et al. 1976; Hadj Zobir 2007) in the Edough massif, Annaba. The aim of this paper is to determine the nature of the peridotite outcrop from Sidi Mohamed.

\section{Geological background}

The Edough massif is the easternmost crystalline massif of the Maghrebides, which represent the south-eastern part of the west Mediterranean orogen. It is an asymmetric 'core complex' (Caby and Hammor 1992) oriented NE-SW (figure 1a), and

Keywords. Peridotites; upper mantle; Edough; Algeria. 

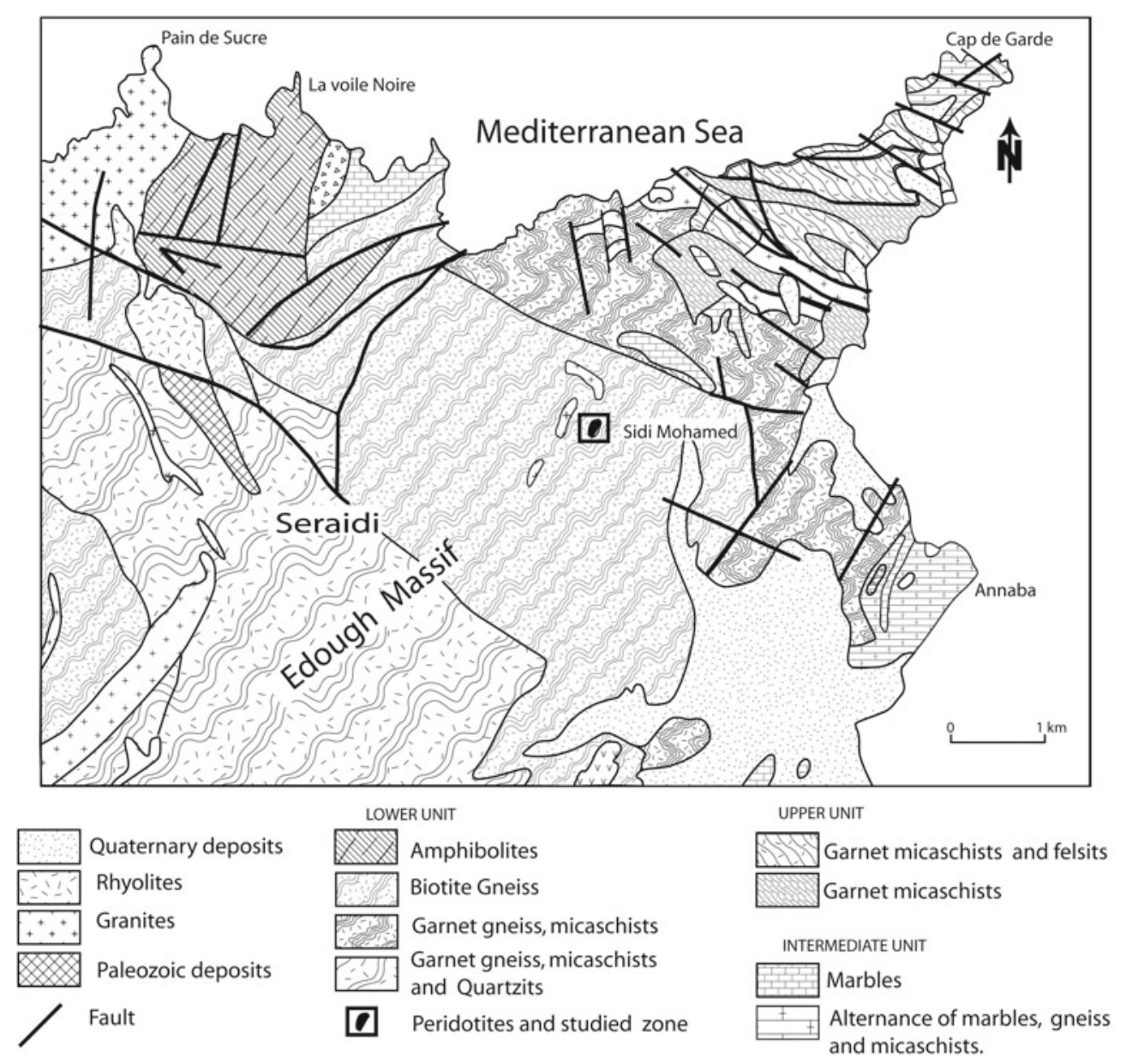

(a)
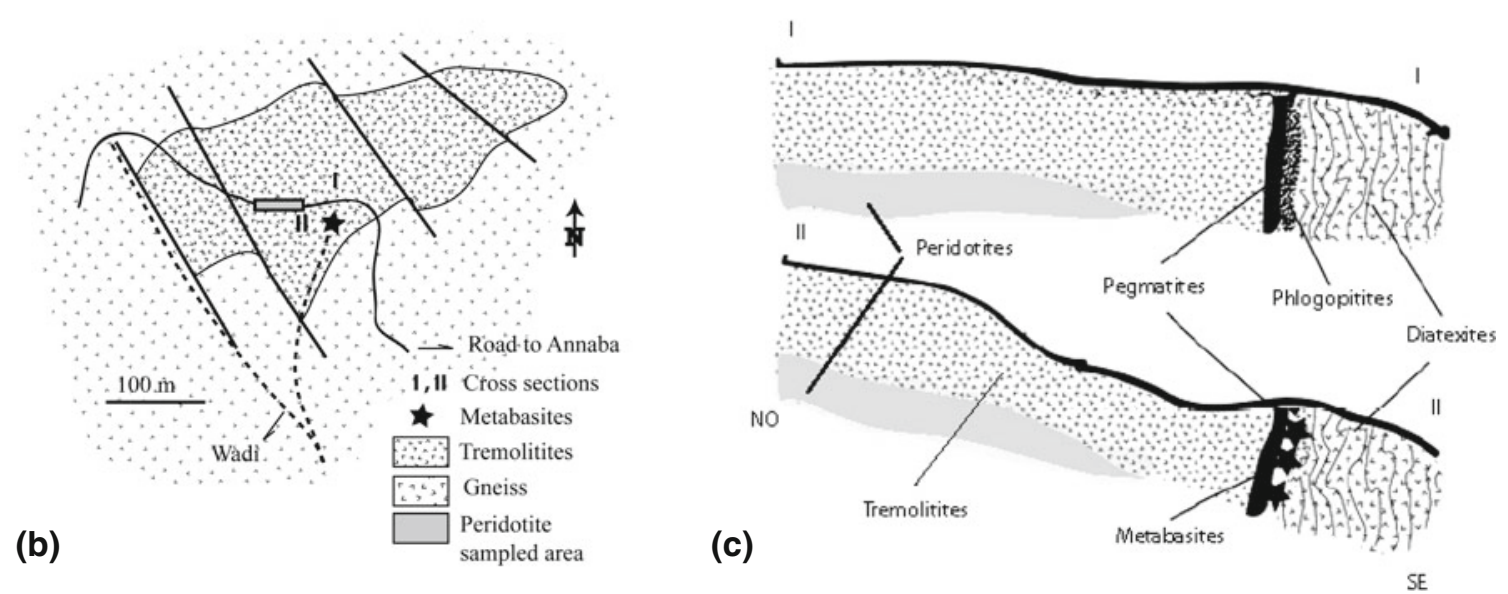

Figure 1. (a) Simplified geological map of the Edough massif (modified after the works of Hilly 1962; SONAREM (Société Nationale De la Recherche Minière) 1980; Gleizes et al. 1988; Caby and Hammor 1992; Ahmed Said and Leake 1992, 1997; Hadj Zobir 2007 and references therein). (b) Simplified geological map of Sidi Mohamed outcrop (Bossière et al. 1976) modified after Hadj Zobir (2007); (c) Cross-section of the Sidi Mohamed outcrop (scale of the cross-section is enlarged to show details. The average thickness of the metabasite is $1 \mathrm{~m})$.

is found below the greenschist-facies Tellian units that represent the thrusted Mesozoic to Eocene passive paleomargin of northern Africa deposited on thinned continental crust. The Edough metamorphic rocks consist of two tectonically superposed units: (1) The lower unit that is composed of weathered magmatic gneisses (diatexites) that have an arkosic source (Hadj Zobir 2012; Hadj Zobir and Mocek 2012). This unit is composed of biotite gneiss and two micas augen-gneiss of Hercynian age (Bruguier et al. 2009). The lower unit gneisses sometimes contains benches of leptynites 
and marbles (Hilly 1962; Gleizes et al. 1988; Ahmed Said et al. 1993), as well as metabasites (Hadj Zobir et al. 2007) occurring as one-meter thick outcrop within the ultrabasic-basic complex. (2) The upper unit that is composed of micaschists.

Between the two main units, an intermediate unit composed of garnet micaschists and kyanitesillimanite-andalusite bearing micaschists and metric benches of marbles is found.

The Edough massif underwent polycyclic metamorphism at crustal-levels that was characterized by three major events: (i) a high grade HT-HP metamorphism $\left(\mathrm{P}=12-13 \mathrm{~kb}, \mathrm{~T}=700^{\circ} \mathrm{C}\right)$ corresponding to the conditions of the granulite facies, (ii) an intermediate prograde metamorphism (MP$\mathrm{MT}$ ), and (iii) a low-pressure metamorphism at high temperature LP-HT $\left(\mathrm{P}=3-4 \mathrm{~kb}, \mathrm{~T}=650^{\circ}-\right.$ $700^{\circ} \mathrm{C}$ ) (Brunnel et al. 1988; Ahmed Said et al. 1993; Caby et al. 2001). Some units suffered only one or two metamorphic events. The massif underwent a first strong strike slip deformation, characterized by syn-metamorphic folds that was followed by less intense contractive deformation, which generated upright folds axes with in a $140^{\circ} \mathrm{N}$ direction, anticlines in a direction of $50^{\circ}-60^{\circ} \mathrm{N}$ and shear distortions in a $120^{\circ}-160^{\circ} \mathrm{N}$ direction.

The peridotites of Sidi Mohamed (figure $1 \mathrm{~b}$ and c) are found within a relatively small outcrop area $\left(0.03 \mathrm{~km}^{2}\right)$ and are enclosed in diatexitic gneiss by tectonic contacts.

The rocks are discordant to the diatexites pointing to strong late reworking. The peridotites are serpentinized (Bossière et al. 1976; Hadj Zobir 2007). The eastern contact between peridotite and diatexite is outlined by small layers of metabasic, pegmatitic rocks, and some pockets of garnet phlogopitites.

\section{Analytical methods}

After examining thin sections of the samples for their mineralogical composition and alteration products the samples were crushed, homogenized and $500 \mathrm{~g}$ splits were used for chemical analyses. Powder of selected unaltered samples was dried overnight at $105^{\circ} \mathrm{C}$ before analyses were conducted. The compositions of the whole-rock samples, including major, minor and trace elements were determined by wavelength dispersive X-ray fluorescence spectrometry (WD-XRF), inductively coupled plasma-mass spectrometry (ICP-MS) and inductively coupled plasma-atomic emission spectrometry (ICP-AE) at laboratories of the GeoForschungsZentrum Potsdam (GFZ) and the Institut für Geowissenschaften, Universität Potsdam, Germany. International and internal reference samples were used for calibration. Analyses for major and minor elements and for trace elements were conducted on fused glass and pressed powder disks respectively. Fused beads were prepared in a ratio of 1:6 of sample powder $(<63 \mu \mathrm{m})$ and the melting agent FLUXANA FX-X 65-2 (99.98\%) (containing $66 \%$ di-lithiumtetraborate and $34 \%$ lithiummetaborate). The mixture was melting on a burner cascade between $400^{\circ}$ and $1150^{\circ} \mathrm{C}$. Powder pellets were prepared from $3 \mathrm{~g}$ sample powder and 3 drops of Moviol (organic glue) under a pressure of $50 \mathrm{nN}$ for about $20 \mathrm{~s}$. Both of the disks were prepared at the Institut für Geowissenschaften, Universität Potsdam, Germany. Major, minor and some of trace elements $(\mathrm{Ni})$ were acquired by Siemens SRS303-AS XRF with an Rh X-ray tube at standard running conditions at GFZ, Germany. Measurements of trace elements, including $\mathrm{Nb}$, were performed in the ICP-MS laboratory at GFZ, Germany, using a VG Elemental Plasma Quad System PQ2+i. REE were analysed at the Institut für Geowissenschaften, Universität Potsdam, Germany by an ICP-OES (Varian Vista MPX) after separation of major and most trace elements. REE were enriched using the method described by Zuleger and Erzinger (1988). The mineral chemical analyses, including major rock forming minerals, accessories and alteration product minerals were conducted using a fully automated CAMECA SX100 electron microprobe at laboratories of GFZ, Germany. The instrument was calibrated with natural mineral standards. Detection limits vary with atomic number and range between 50 and $100 \mathrm{ppm}$.

\section{Sample description}

Six whole-rock samples were systematically collected across the freshest parts of the peridotites. Sampling was done along a W-E transect within a distance of $100 \mathrm{~m}$. The mineralogic composition of the peridotite is mostly olivine and orthopyroxene with minor amounts of clinopyroxene (diopside) and their alteration products, serpentine and chlorite (figure $2 \mathrm{a}$ and $\mathrm{b}$ ). The original assemblages are partially transformed to mesh-textured serpentine after olivine, tremolitic amphibole after pyroxene and Mg-chlorite after pyroxene and olivine. The samples originally displayed a porphyroclastic texture. Diopside is light green in fresh samples, but is often replaced by calcic amphibole (tremolite). Neither thin section nor microprobe or XRD studies, found evidence of identifying an aluminous phase such as Al-spinel, garnet or plagioclase. The high $\mathrm{Al}_{2} \mathrm{O}_{3}$ content in some samples, however, indicates that an aluminous phase was present in the primary mode of the peridotite. The primary modal 


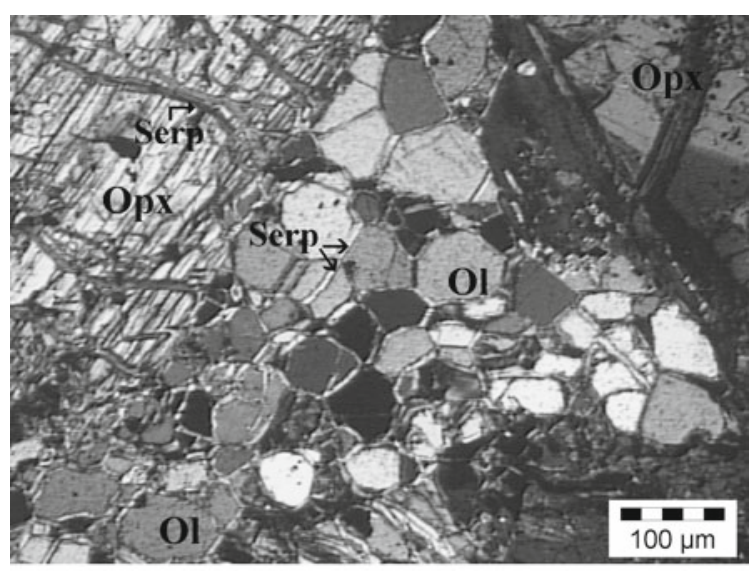

(a)

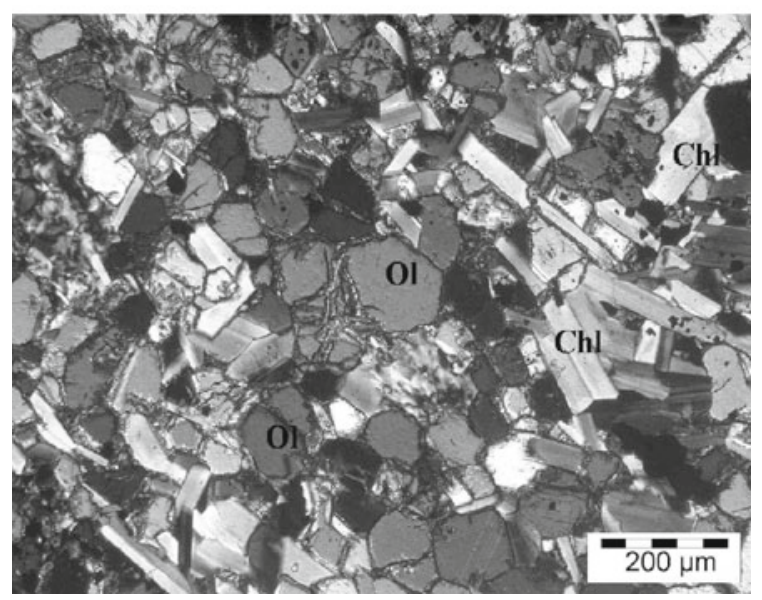

(b)

Figure 2. Cross-polarized photomicrograph showing (a) olivine crystals and porphyroclastic texture of orthopyroxenes, (b) subangular-to-subrounded olivine grains separated by serpentine veinlets in contact with some $\mathrm{Mg}$-chlorite.

composition of the primary rocks ranges from 63-65 vol.\% olivine, 18-20 vol.\% orthopyroxene, 1-3 vol.\% clinopyroxene and 12 vol.\% other minerals (chlorite, serpentine, talc, brucite). In the peridotite classification diagram, all samples plot in the harzburgite field (figure 3). Based on the amount of clinopyroxene (1 vol.\% in N-harzburgites and 2-3 vol.\% in Cpx-harzburgites), we distinguish two types of peridotites: normal harzburgites (Nharzburgites, samples K7.8, K7.9 and K7.18) and clinopyroxene-rich harzburgites (Cpx-harzburgites, samples K7.10, K7.6 and K7.15). Apart from clinopyroxene content, there is no significant difference in mineral mode between the samples. Most olivine has serpentinized rim. In some thin sections, a few olivine crystals are well preserved locally and occur as small (generally $<0.5-2 \mathrm{~mm}$ ) grains that consist of subangular to subrounded kernels separated by serpentine veinlets and secondary magnetite. Small grains of olivine are partially enclosed in large orthopyroxenes. Enstatite and clinopyroxene (diopside) range between 0.1 and

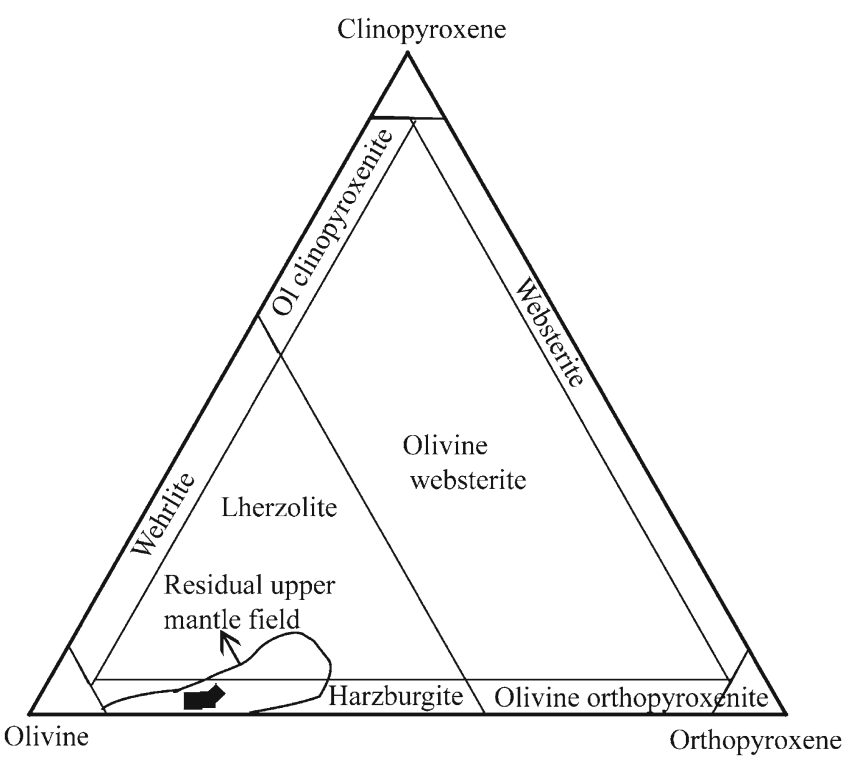

Figure 3. Modal compositions of Sidi Mohamed peridotites in the peridotite classification diagram. The area is the field of Residual Upper Mantle field after Michel and Bonatti (1985) and Dick (1989).

$8 \mathrm{~mm}$ in diameter, but most clinopyroxene grains are $<1 \mathrm{~mm}$. Some porphyroclastes of orthopyroxene show inclusions of oxide (magnetite) and olivine. Occasionally, orthopyroxene shows exsolution lamellae of clinopyroxene. Clinopyroxene is mostly found in interstitial spaces associated with orthopyroxene and/or chlorite in the serpentinized matrix.

\section{Whole rock and mineral chemistry}

\subsection{Whole rock chemistry}

Whole rock major and trace element data for six representative peridotite samples from Sidi Mohamed are given in table 1 . Only samples with a low degree of serpentinization were taken for chemical analysis. Due to widespread serpentinization, the analyzed samples show high values of loss on ignition (7.9-12.3 wt.\%) but fairly homogeneous compositions. N-harzburgite samples contain $\mathrm{MgO}$ varying from 33.14 to 35.9 wt. $\%$ and $\mathrm{FeO}_{\text {tot }}$ from 7.3 to 9.82 wt. $\% . \mathrm{Al}_{2} \mathrm{O}_{3}, \mathrm{CaO}, \mathrm{TiO}_{2}$ contents range from 0.8 to 1.4 wt. $\%, 0.23$ to 0.92 wt. $\%, 0.03$ to 0.04 wt.\%, respectively and $\mathrm{Na}_{2} \mathrm{O}$ varies from 0.02 to 0.05 wt.\%. Ni ranges from 2051 to $2920 \mathrm{ppm}$ and $\mathrm{Cr}$ from 2738 to 5514 ppm. V concentration varies from 32 to $43 \mathrm{ppm}$. The large-ion lithophile elements (LILE) show very low abundances in all samples. The concentrations of $\mathrm{Rb}$ range in $\mathrm{N}$ harzburgites between 1.1 and $1.25 \mathrm{ppm}, \mathrm{Ba}$ varies from 17 to $75 \mathrm{ppm}$ and $\mathrm{Nb}$ from 0.09 to $0.19 \mathrm{ppm}$.

Cpx-harzburgites show lower $\mathrm{MgO}$ concentrations than N-harzburgites: $\mathrm{MgO}$ varies from 28.49 
Table 1. Chemical composition of the peridotites from Sidi Mohamed outcrop.

\begin{tabular}{|c|c|c|c|c|c|c|}
\hline \multirow[b]{2}{*}{ Wt.\% } & \multicolumn{3}{|c|}{ N-harzburgites } & \multicolumn{3}{|c|}{ Cpx-harzburgites } \\
\hline & K7.8 & K7.9 & K7.18 & K7.10 & K7.6 & K7.15 \\
\hline $\mathrm{SiO}_{2}$ & 46.60 & 40.10 & 46.75 & 46.1 & 44.7 & 45 \\
\hline $\mathrm{TiO}_{2}$ & 0.03 & 0.04 & 0.04 & 0.06 & 0.16 & 0.14 \\
\hline $\mathrm{Al}_{2} \mathrm{O}_{3}$ & 0.80 & 1.4 & 0.9 & 1.7 & 2.56 & 2.6 \\
\hline $\mathrm{FeO}_{\text {tot }}$ & 8.59 & 9.82 & 7.3 & 13.58 & 10.22 & 8.12 \\
\hline $\mathrm{MnO}$ & 0.14 & 0.12 & 0.125 & 0.14 & 0.14 & 0.12 \\
\hline $\mathrm{MgO}$ & 34.15 & 35.9 & 33.14 & 28.71 & 28.49 & 28.75 \\
\hline $\mathrm{CaO}$ & 0.23 & 0.92 & 0.6 & 1.53 & 1.86 & 2.07 \\
\hline $\mathrm{Na}_{2} \mathrm{O}$ & 0.05 & 0.05 & 0.02 & 0.1 & 0.06 & 0.07 \\
\hline $\mathrm{K}_{2} \mathrm{O}$ & 0.02 & 0.02 & 0.02 & 0.3 & 0.02 & 0.02 \\
\hline $\mathrm{P}_{2} \mathrm{O}_{5}$ & 0.03 & 0.03 & 0.03 & 0.02 & 0 & 0.03 \\
\hline L.O.I & 8.55 & 10.50 & 11.3 & 7.9 & 11.2 & 12.3 \\
\hline Total & 99.19 & 98.9 & 100.22 & 100.14 & 99.41 & 99.22 \\
\hline \multicolumn{7}{|l|}{ ppm } \\
\hline $\mathrm{Ba}$ & 17 & 57 & 75 & 76 & 106 & 13 \\
\hline $\mathrm{Rb}$ & nd & 1.1 & 1.25 & 1.7 & 0.33 & 1 \\
\hline $\mathrm{Cr}$ & 2738 & 5514 & 3483 & 2368 & 2515 & 3200 \\
\hline $\mathrm{Ni}$ & 2920 & 2918 & 2051 & 2504 & 2179 & 2243 \\
\hline V & 32 & 43 & 38.5 & 61 & 55 & 63 \\
\hline $\mathrm{Sc}$ & 10 & 13 & 12 & 10 & 18 & 16 \\
\hline $\mathrm{Nb}$ & nd & 0.09 & 0.19 & 0.12 & 0.11 & 0.13 \\
\hline $\mathrm{La}$ & 1.1 & 0.2 & 0.95 & 1.2 & 1.33 & 0.38 \\
\hline $\mathrm{Ce}$ & 1.2 & 0.24 & 1.57 & 1.2 & 1.65 & 0.44 \\
\hline $\operatorname{Pr}$ & 0.13 & 0.03 & 0.33 & 0.15 & 0.32 & 0.09 \\
\hline $\mathrm{Nd}$ & 0.53 & 0.21 & 1.61 & 0.97 & 1.32 & 0.75 \\
\hline $\mathrm{Sm}$ & 0.11 & 0.05 & 0.325 & 0.25 & 0.52 & 0.24 \\
\hline $\mathrm{Eu}$ & 0.01 & 0.01 & 0.04 & 0.07 & 0.06 & 0.07 \\
\hline $\mathrm{Gd}$ & 0.19 & 0.12 & 0.46 & 0.41 & 0.56 & 0.39 \\
\hline $\mathrm{Tb}$ & 0.03 & 0.02 & 0.08 & 0.06 & 0.07 & 0.05 \\
\hline Dy & 0.18 & 0.13 & 0.17 & 0.43 & 0.57 & 0.42 \\
\hline Но & 0.03 & 0.03 & 0.09 & 0.09 & 0.04 & 0.09 \\
\hline Er & 0.16 & 0.11 & 0.26 & 0.3 & 0.41 & 0.3 \\
\hline $\mathrm{Tm}$ & 0.04 & 0.03 & 0.05 & 0.05 & 0.04 & 0.04 \\
\hline $\mathrm{Yb}$ & 0.2 & 0.13 & 0.22 & 0.32 & 0.41 & 0.31 \\
\hline $\mathrm{Lu}$ & 0.03 & 0.02 & 0.06 & 0.05 & 0.04 & 0.05 \\
\hline
\end{tabular}

to 28.75 wt.\%, $\mathrm{FeO}_{\text {tot }}$ from 8.12 to 13.58 wt.\%. $\mathrm{Al}_{2} \mathrm{O}_{3}, \mathrm{CaO}, \mathrm{TiO}_{2}$ contents in Cpx-harzburgites range from 1.7 to 2.6 wt. $\%, 1.53$ to 2.07 wt.\% and 0.06 to 0.16 wt.\%, respectively. $\mathrm{Na}_{2} \mathrm{O}$ content in Cpx-harzburgites (0.06-0.1 wt.\%) is higher than in N-harzburgites. The Cpx-harzburgite samples show Ni contents of 2179 to $2504 \mathrm{ppm}$ and $\mathrm{Cr}$ of 2368-3200 ppm. Due to high abundance in pyroxenes, the Cpx-harzburgites show higher V concentration (55-63 ppm) than in N-harzburgites. The concentration of $\mathrm{Rb}$ ranges from 0.33 to $1.7 \mathrm{ppm}$, $\mathrm{Ba}$ varies from 13 to $106 \mathrm{ppm}$ and $\mathrm{Nb}$ from 0.11 to $0.13 \mathrm{ppm}$.

In terms of incompatible trace elements, the Sidi Mohamed peridotites have relatively homogeneous compositions and display flat to slightly concave- upward patterns. REE contents vary significantly, with variable ranges for most of the REE composition in the N-harzburgite: La varies from 0.2 to $1.1 \mathrm{ppm}$, Ce from 0.24 to $1.57 \mathrm{ppm}$, and $\mathrm{Eu}$ from 0.01-0.04 ppm. The Cpx-harzburgites have higher REE concentrations: $\mathrm{La}=0.38-1.33 \mathrm{ppm}$, and $\mathrm{Eu}$ from 0.06-0.07 ppm. In mantle-normalized (Sun and McDonough 1989), the two types of harzburgites show slight apparent negative $\mathrm{Nb}$ and $\mathrm{Eu}$ anomalies and nearly flat but slightly depleted REE patterns.

\subsection{Mineral chemistry}

All primary minerals show highly refractory compositions: olivine is highly magnesian ( $\left.\mathrm{Fo}_{94.65-94.72}\right)$ 
Table 2. Chemical composition of olivine and their structural formula.

\begin{tabular}{|c|c|c|c|c|c|c|}
\hline \multirow[b]{2}{*}{ Wt. \% } & \multicolumn{3}{|c|}{ N-harzburgites } & \multicolumn{3}{|c|}{ Cpx-harzburgites } \\
\hline & $\mathrm{K} 7.8 \mathrm{a}$ & $\mathrm{K} 7.8 \mathrm{~b}$ & $\mathrm{~K} 7.8 \mathrm{c}$ & $\mathrm{K} 7.10 \mathrm{~b}$ & $\mathrm{~K} 7.10 \mathrm{~b}$ & $\mathrm{~K} 7.10 \mathrm{c}$ \\
\hline $\mathrm{SiO}_{2}$ & 41.58 & 41.04 & 41.67 & 41.84 & 41.89 & 41.1 \\
\hline $\mathrm{TiO}_{2}$ & nd & nd & 0.01 & nd & nd & 0.03 \\
\hline $\mathrm{Al}_{2} \mathrm{O}_{3}$ & nd & 0.01 & 0 & 0.02 & nd & nd \\
\hline $\mathrm{Cr}_{2} \mathrm{O}_{3}$ & nd & nd & 0.02 & 0.01 & nd & nd \\
\hline $\mathrm{FeO}$ & 5.14 & 5.1 & 5.23 & 5.15 & 5.17 & 5.18 \\
\hline $\mathrm{MnO}$ & 0.12 & 0.15 & 0.16 & 0.14 & 0.13 & 0.19 \\
\hline $\mathrm{MgO}$ & 51.85 & 52.93 & 53.45 & 53.06 & 52.9 & 52.4 \\
\hline $\mathrm{NiO}$ & 0.45 & 0.46 & 0.49 & 0.54 & 0.57 & 0.56 \\
\hline $\mathrm{CaO}$ & 0.20 & 0.01 & nd & nd & 0.01 & nd \\
\hline Total & 99.15 & 99.71 & 101.03 & 100.75 & 100.67 & 99.47 \\
\hline \multicolumn{7}{|l|}{$\operatorname{mol~} \%$} \\
\hline Fo & 94.7 & 94.72 & 94.65 & 94.71 & 94.69 & 94.66 \\
\hline $\mathrm{Fa}$ & 5.18 & 5.12 & 5.19 & 5.15 & 5.18 & 5.15 \\
\hline $\mathrm{Tp}$ & 0.12 & 0.16 & 0.16 & 0.14 & 0.13 & 0.19 \\
\hline
\end{tabular}

Table 3. Chemical composition of pyroxenes: (a) of orthopyroxenes and (b) of clinopyroxene.

\begin{tabular}{|c|c|c|c|c|c|c|c|c|}
\hline \multirow{2}{*}{$\begin{array}{l}\text { a) } \\
\text { Wt. } \%\end{array}$} & \multicolumn{6}{|c|}{ N-harzburgites } & \multirow{2}{*}{\multicolumn{2}{|c|}{$\frac{\text { Cpx-harzburgitesq }}{\text { K7.10 }}$}} \\
\hline & & K7.8 & & & K7.9 & & & \\
\hline $\mathrm{SiO}_{2}$ & 59.48 & 59.67 & 59.88 & 59.84 & 59.79 & 59.34 & 59.71 & 59.6 \\
\hline $\mathrm{TiO}_{2}$ & 0.02 & nd & nd & 0.01 & nd & nd & nd & nd \\
\hline $\mathrm{Al}_{2} \mathrm{O}_{3}$ & 0.09 & 0.06 & 0.09 & 0.08 & 0.07 & 0.09 & 0.12 & 0.1 \\
\hline $\mathrm{FeO}_{(\mathrm{t})}$ & 3.71 & 4.16 & 3.64 & 3.51 & 3.63 & 3.67 & 4.14 & 4.04 \\
\hline $\mathrm{MnO}$ & 0.17 & 0.27 & 0.17 & 0.15 & 0.16 & 0.21 & 0.18 & 0.18 \\
\hline $\mathrm{MgO}$ & 37.44 & 37.25 & 37.38 & 37.34 & 37.3 & 36.86 & 37.27 & 37.24 \\
\hline $\mathrm{CaO}$ & 0.1 & 0.02 & 0.16 & 0.12 & 0.14 & 0.13 & 0.14 & 0.14 \\
\hline $\mathrm{Na}_{2} \mathrm{O}$ & 0.01 & 0.02 & nd & 0.01 & nd & 0.01 & 0.01 & nd \\
\hline $\mathrm{K}_{2} \mathrm{O}$ & nd & nd & nd & nd & nd & nd & nd & 0.01 \\
\hline $\mathrm{Cr}_{2} \mathrm{O}_{3}$ & 0.02 & 0.04 & 0.05 & nd & 0.04 & nd & 0.02 & 0.03 \\
\hline Total & 101.04 & 101.48 & 101.37 & 101.06 & 101.12 & 100.32 & 101.58 & 101.34 \\
\hline \multicolumn{9}{|l|}{ mol \% } \\
\hline Wo & 0.19 & 0.03 & 0.28 & 0.22 & 0.25 & 0.24 & 0.25 & 0.26 \\
\hline En & 94.29 & 93.66 & 94.32 & 94.55 & 94.38 & 94.16 & 93.66 & 93.78 \\
\hline Fs & 5.48 & 6.25 & 5.4 & 5.19 & 5.37 & 5.56 & 6.08 & 5.96 \\
\hline b) & \multicolumn{2}{|c|}{ N-harzburgites } & \multicolumn{2}{|c|}{ Cpx-harzburgites } & & & & \\
\hline Wt. \% & K7.8a & $\mathrm{K} 7.8 \mathrm{~b}$ & K7.10a & $\mathrm{K} 7.10 \mathrm{~b}$ & & & & \\
\hline $\mathrm{SiO}_{2}$ & 54.87 & 54.37 & 53.74 & 54.48 & & & & \\
\hline $\mathrm{TiO}_{2}$ & 0 & 0.05 & nd & 0.01 & & & & \\
\hline $\mathrm{Al}_{2} \mathrm{O}_{3}$ & 0.21 & 0.19 & 0.1 & 0.08 & & & & \\
\hline $\mathrm{FeO}_{(\mathrm{t})}$ & 1.7 & 1.67 & 1.76 & 1.79 & & & & \\
\hline $\mathrm{MnO}$ & 0.12 & 0.19 & 0.17 & 0.25 & & & & \\
\hline $\mathrm{MgO}$ & 17.92 & 18.01 & 18.63 & 18.24 & & & & \\
\hline $\mathrm{CaO}$ & 25.22 & 25.19 & 24.82 & 24.82 & & & & \\
\hline $\mathrm{Na}_{2} \mathrm{O}$ & 0.02 & 0 & 0.05 & 0.04 & & & & \\
\hline $\mathrm{K}_{2} \mathrm{O}$ & 0.02 & 0.01 & nd & 0.05 & & & & \\
\hline $\mathrm{Cr}_{2} \mathrm{O}_{3}$ & nd & 0.02 & 0.02 & 0.04 & & & & \\
\hline Total & 100.08 & 99.69 & 99.27 & 99.78 & & & & \\
\hline \multicolumn{9}{|l|}{$\operatorname{mol} \%$} \\
\hline Wo & 48.87 & 48.72 & 47.43 & 47.87 & & & & \\
\hline En & 48.3 & 48.47 & 49.53 & 48.94 & & & & \\
\hline $\mathrm{Fs}$ & 2.76 & 2.8 & 2.88 & 3.07 & & & & \\
\hline
\end{tabular}


(a)
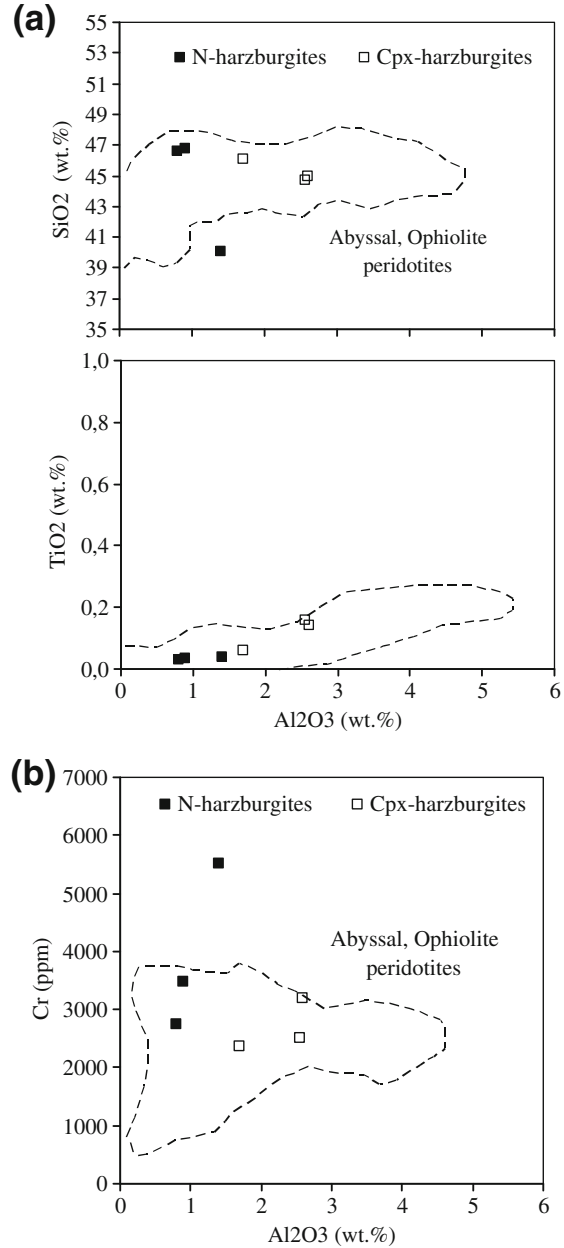

(c)
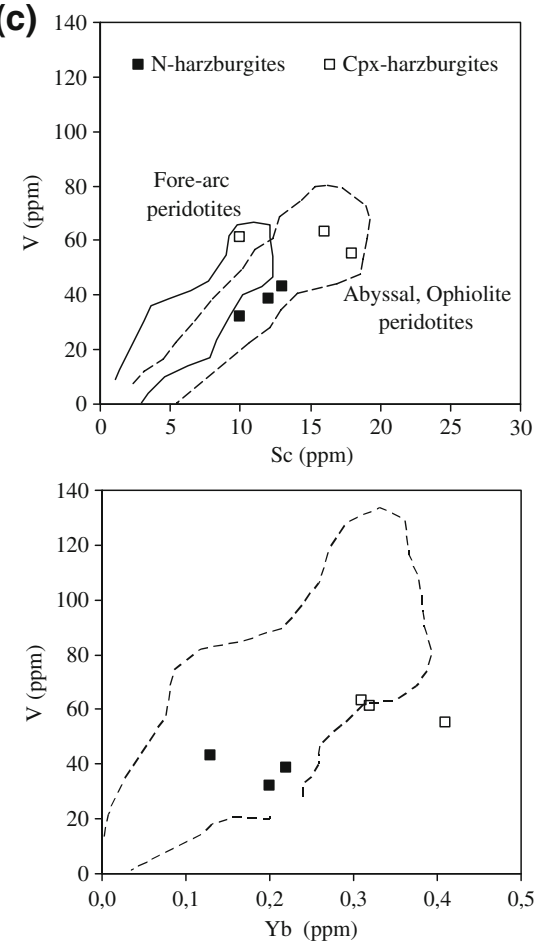
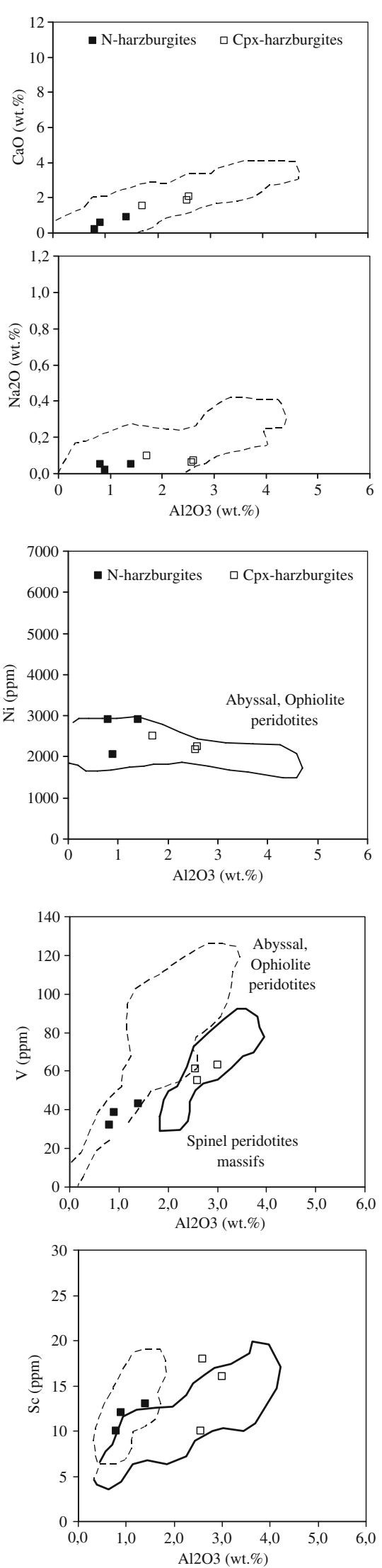

Figure 4. Compositions of Sidi Mohamed peridotites compared with literature data for mantle peridotites (Bodinier and Godard 2003): (a) Major element oxides: $\mathrm{SiO}_{2}, \mathrm{CaO}, \mathrm{TiO}_{2}$ and $\mathrm{Na}_{2} \mathrm{O}$ vs. $\mathrm{Al}_{2} \mathrm{O}_{3}$ (Bodinier and Godard 2003), (b) trace elements $\mathrm{Cr}$ and $\mathrm{Ni}$ vs. $\mathrm{Al}_{2} \mathrm{O}_{3}$ (Bodinier and Godard 2003), and (c) V vs. Sc, $\mathrm{Yb}, \mathrm{Al}_{2} \mathrm{O}_{3}$ and $\mathrm{Sc}$ vs. $\mathrm{Al}_{2} \mathrm{O}_{3}$ (Canil 2004). 
and its $\mathrm{NiO}$ increases from 0.45 wt.\% in $\mathrm{N}$ harzburgites to 0.57 wt.\% in the Cpx-harzburgites (table 2). Orthopyroxene is also very magnesian (En $\left.{ }_{93.66-94.55}\right)$ in all samples. In N-harzburgites, it shows a very low wollastonite component (0.03$0.28 \mathrm{~mole} \%) . \mathrm{Cr}_{2} \mathrm{O}_{3}$ content is insignificantly low $\left(\leq 0.05\right.$ wt.\%), $\mathrm{Al}_{2} \mathrm{O}_{3}$ and $\mathrm{TiO}_{2}$ are very low, ranging between $0.06-0.09$ wt. $\%$ and $\leq 0.02$ wt.\%, respectively (table $3 \mathrm{a}$ ). $\mathrm{MnO}$ and $\mathrm{CaO}$ contents of orthopyroxenes in all samples are also low, $0.15-0.27$ wt.\% and $0.02-0.16$ wt.\%, respectively. Orthopyroxene from N-harzburgite has a higher $\mathrm{CaO}$ content than the orthopyroxenes from Cpxharzburgites.

All harzburgite samples contain diopside $\left(\mathrm{En}_{48.3-49.53} \mathrm{Wo}_{47.43-48.87} \mathrm{Fs}_{2.76-3.07}\right)$ (table 3b). There is no significant change in $\mathrm{FeO}$ (1.67-1.79 wt.\%) from one sample to another. The N-harzburgite clinopyroxenes have slightly higher values in $\mathrm{CaO}$ (25.19-25.22 wt.\%) and $\mathrm{Na}_{2} \mathrm{O}(\leq 0.02$ wt.\%) than the Cpx-harzburgite clinopyroxenes (24.82 wt.\% $\mathrm{CaO}$ and $0.04-0.05$ wt.\% $\left.\mathrm{Na}_{2} \mathrm{O}\right)$. The diopsides are Ti-poor $\left(\leq 0.05\right.$ wt. $\left.\% \mathrm{TiO}_{2}\right)$ and have a low Al-content (0.08-0.21 wt.\% $\left.\mathrm{Al}_{2} \mathrm{O}_{3}\right)$ in general.

Secondary minerals are represented by serpentine, chlorite, amphibole and oxides (magnetite). Serpentine is antigorite (identified by XRD) with a high $\mathrm{MgO}$ content. Chlorite is Mg-rich and its compositions vary between chamosite and clinochlore. Amphibole that replaces diopside is tremolite, which contains very small amounts of $\mathrm{FeO}$ and $\mathrm{Na}_{2} \mathrm{O}$.

\section{Geothermometry}

The $\mathrm{P}-\mathrm{T}$ conditions for the formation of Sidi Mohamed peridotites were calculated on the basis of pyroxene compositions. The $\mathrm{T}_{\mathrm{Ca}}$ in Opx (Brey and Köhler 1990) geothermometer was used to get the minimum temperature. The $\mathrm{T}_{\mathrm{Ca}}$ in Opx give a temperature range of $691-716 \pm 60^{\circ} \mathrm{C}$. The low temperatures recorded by the Sidi Mohamed peridotites are lower than expected from mantle peridotites. These temperatures are not exceptional in metasomatized and re-equilibrated peridotites, however, Parkinson and Pearce (1998) calculated that temperatures for ODP Leg 125 peridotites were $647 \pm$ $40^{\circ} \mathrm{C}$ and $806 \pm 75^{\circ} \mathrm{C}$ for abyssal peridotites, and reported mean temperatures of $658 \pm 49^{\circ} \mathrm{C}$ for Leg 125 peridotites and $747 \pm 97^{\circ} \mathrm{C}$ for abyssal peridotites.

\section{Discussion}

The chemistry of the Sidi Mohamed N-harzburgite $\left(\mathrm{MgO}=33.14-35.9\right.$ wt.\%, $\mathrm{SiO}_{2}=40.1-46.75$ wt.\%, $\mathrm{FeO}_{\text {tot }}=7.3-9.82$ wt.\%, $\mathrm{Cr}=2738-5514 \mathrm{ppm}$ and $\mathrm{Ni}=2051-2920 \mathrm{ppm}$ ) compares well with mantle values of fresh peridotites $(\mathrm{MgO}=35-46$ wt.\%, $\mathrm{SiO}_{2}=43-46$ wt. $\%, \mathrm{FeO}_{\text {tot }}=8 \pm 1$ wt. $\%, \mathrm{Cr}=$ $2700 \pm 700 \mathrm{ppm}$ and $\mathrm{Ni}=2200 \pm 500 \mathrm{ppm}$ ) (O'Neill and Palme 1998). The chemistry of Cpxharzburgites $\left(\mathrm{MgO}=28.49-28.75\right.$ wt. $\%, \mathrm{SiO}_{2}=$ $44.7-46.1$ wt. $\%, \mathrm{FeO}_{\text {tot }}=8.12-13.58$ wt. $\%, \mathrm{Cr}=$ 2368 $-3200 \mathrm{ppm}$ and $\mathrm{Ni}=2179-2504 \mathrm{ppm}$ ) reflects their high enrichment in clinopyroxenes (significant loss in $\mathrm{MgO}$ and gain in $\mathrm{FeO}_{\text {tot }}$ ). The Sidi Mohamed harzburgites are primitive as expressed by their high $\mathrm{Cr}$ and low $\mathrm{SiO}_{2}$ content and plot near the field of mantle peridotites as defined by Dick (1989) and Snow and Dick (1995). The samples plot in the residual upper mantle field (Michel and Bonatti 1985; Dick 1989) (figure 3).

The depleted character of the N-harzburgite is confirmed by very low $\mathrm{Al}_{2} \mathrm{O}_{3}$ and $\mathrm{CaO}$ contents. Compared to the N-harzburgite samples, Cpx-harzburgites are fertile, displaying a lower $\mathrm{MgO}$ content $\left(\sim 28\right.$ wt.\%) and higher $\mathrm{Al}_{2} \mathrm{O}_{3}$ $(\sim 2.29$ wt.\%) and $\mathrm{CaO}$ contents $(\sim 1.82$ wt.\%). Whole rock $\mathrm{Al}_{2} \mathrm{O}_{3}$ and $\mathrm{TiO}_{2}$ concentrations in all samples show a positive correlation from $\mathrm{N}$ harzburgite to Cpx-harzburgite; this feature is interpreted as the effect of clinopyroxene enrichment in the rocks. The covariation diagrams

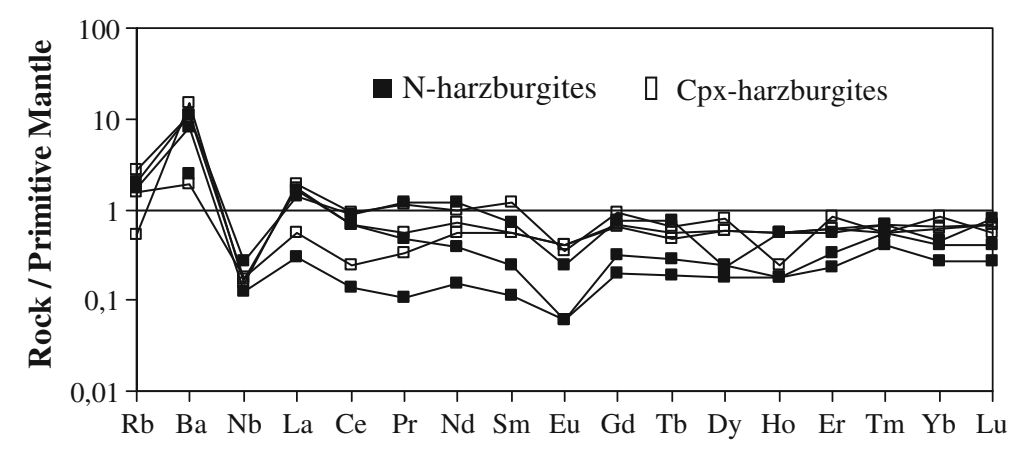

Figure 5. Primitive mantle-normalized multi-element diagrams for Sidi Mohamed peridotites; primitive mantle values after Sun and McDonough (1989). 
(figure 4a and b) of $\mathrm{SiO}_{2}, \mathrm{CaO}, \mathrm{Na}_{2} \mathrm{O}, \mathrm{TiO}_{2}$ vs. $\mathrm{Al}_{2} \mathrm{O}_{3}$ and $\mathrm{Cr}, \mathrm{Ni}$ vs. $\mathrm{Al}_{2} \mathrm{O}_{3}$ show that all samples plot in the mantle peridotite field (orogenic, ophiolitic and abyssal) from Bodinier and Godard (2003). In trace element binary diagrams $\mathrm{V}$ vs. $\mathrm{Sc}, \mathrm{Yb}, \mathrm{Al}_{2} \mathrm{O}_{3}$ and $\mathrm{Sc}$ vs. $\mathrm{Al}_{2} \mathrm{O}_{3}$ (Canil 2004), the Sidi Mohamed samples plot also within the mantle (orogenic, ophiolitic and abyssal) peridotites areas (figure 4c). The high concentration in $\mathrm{Rb}$ and $\mathrm{Ba}$ and the occurrence of phlogopitites and amphibolites in the outcrop indicates that the rocks underwent a metasomatic event.

REE are generally considered immobile during metamorphism (e.g., Campbell et al. 1984; Lesher et al. 1986). Primitive-mantle normalised multi-element plots for the harzburgites from Sidi Mohamed are presented in figure 5, the normalising values are from Sun and McDonough (1989). The Sidi Mohamed peridotites show parallel, relatively flat and slightly HREE depleted patterns (figure 5). All samples show weak LREE enrichment relative to $\operatorname{HREE}(\mathrm{La} / \mathrm{Yb})_{\mathrm{N}}=0.9-3.9$ and negative $\mathrm{Eu}$
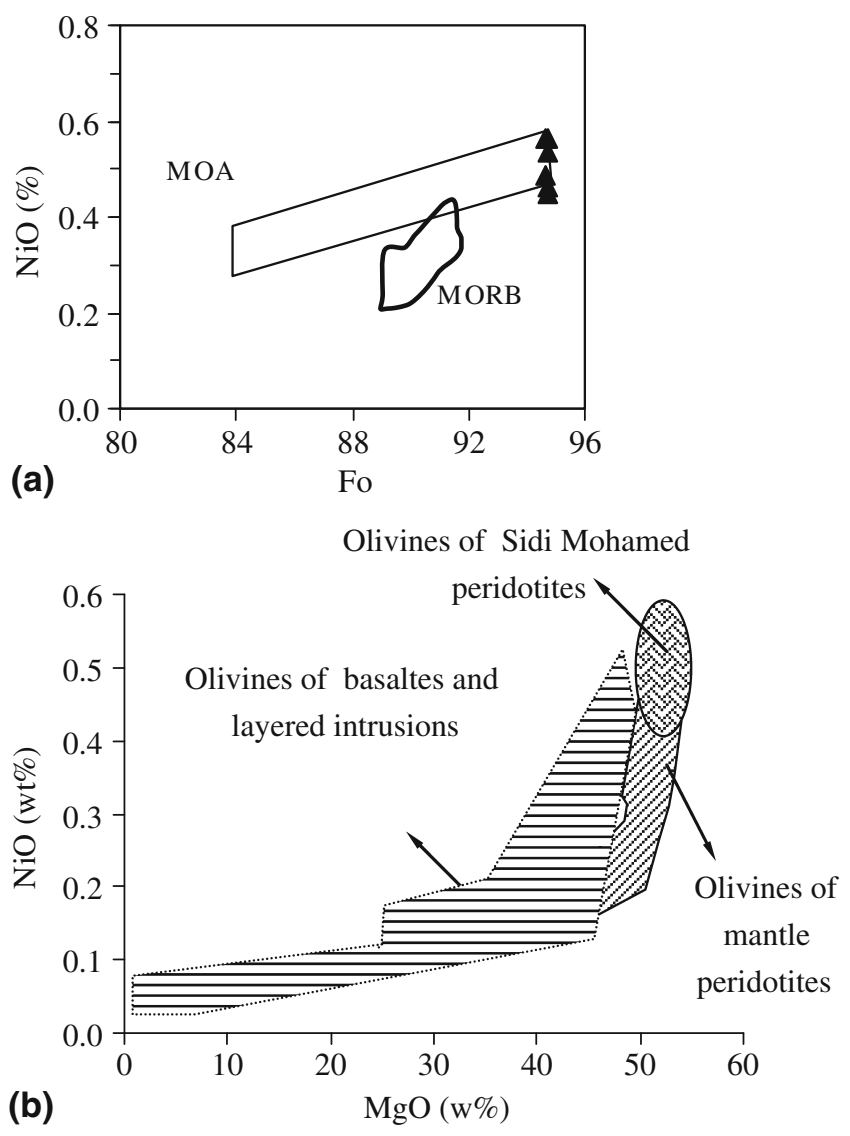

Figure 6. Geochemical comparison of the Sidi Mohamed olivines with mantle and igneous olivines of known environments: (a) Olivine $\mathrm{NiO}$ vs. Fo diagram after Takahashi et al. (1987), (b) Olivine $\mathrm{NiO}$ vs. $\mathrm{MgO}$ diagram after Fleet et al. (1977). MOA: Mantle olivine array, MORB: Field of olivine from mid-oceanic ridges. anomalies $\left(\mathrm{Eu} / \mathrm{Eu}^{*}=0.07-0.46\right)$. The Eu anomaly in ultramafic rocks results from redox conditions during metasomatism (McCammon et al. 2001) and indicates lack of plagioclase.

$\operatorname{High}\left((\mathrm{La} / \mathrm{Gd})_{\mathrm{N}}=1.44-5\right)$ and low $\left((\mathrm{Gd} / \mathrm{Yb})_{\mathrm{N}}=\right.$ 0.7-1.1) ratios of the Sidi Mohamed harzburgites are good indicators of mantle metasomatism (Gruau et al. 1995) or melt-mantle interaction (Zhou et al. 2005). The apparent depletion of Ce might be rather obvious from a slight enrichment of La which in turn may be due to metasomatism. The least serpentinized samples show the highest LREE contents, close to the primitive mantle values. The $\mathrm{Nb}$ anomalies $(\mathrm{Nb} / \mathrm{La}=0.08-0.43)$, relative to the neighbouring elements, suggest a subduction environment.

The Sidi Mohamed olivine is highly magnesian with a large forsterite number (Fo\#; $\mathrm{Mg} / \mathrm{Mg}+$ $\left.\mathrm{Fe}^{*} 100\right)>94$. Such values are typical of residual mantle or metamorphic rocks. Their weight percentage of $\mathrm{NiO}(0.45-0.57$ wt.\%) indicates an upper mantle nature (Arai 1987). Plots of olivine in the bivariate diagrams wt.\% $\mathrm{Ni}$ vs. Fo\# from Takahashi (Takahashi et al. 1987) and wt.\% Ni vs. $\mathrm{MgO}$ from Fleet (Fleet et al. 1977) confirm their mantle nature (figure 6).

The orthopyroxenes indicate an igneous and mantle-related composition (figure 7) (Bhattacharyya 1971; Rietmeijer 1983). With regard to the primary mantle clinopyroxenes $\left(\mathrm{TiO}_{2}=0-0.97\right.$ wt.\%), the Sidi Mohamed diopsides are Ti-poor $(\leq 0.05$ wt. $\%$ $\left.\mathrm{TiO}_{2}\right)$ and show lower Al-content (0.08-0.21 wt.\%

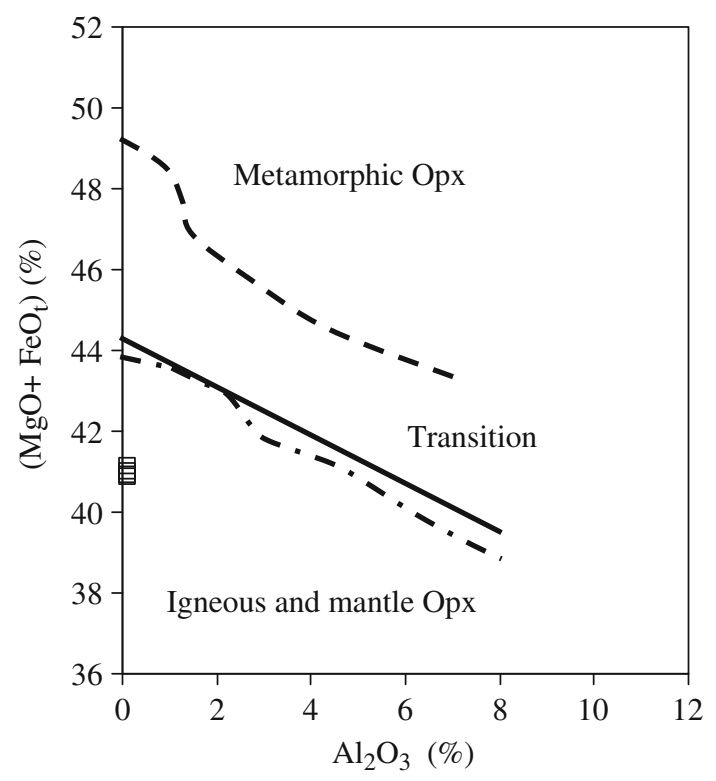

Figure 7. $\left(\mathrm{MgO}+\mathrm{FeO}_{\text {tot }}\right)$ vs. $\mathrm{Al}_{2} \mathrm{O}_{3}$ diagram of Bhattacharyya (1971) modified after Rietmeijer (1983) showing nonmetamorphic and mantle origin of the orthopyroxenes of the Edough Massif peridotites. 
$\left.\mathrm{Al}_{2} \mathrm{O}_{3}\right)$. The abundances of these elements as well as of $\mathrm{Na}_{2} \mathrm{O}(0.02-0.04 \%)$ and $\mathrm{Cr}(\leq 0.04 \%)$ in the clinopyroxenes of Sidi Mohamed are comparable to those from ophiolitic and oceanic peridotites (Kornprobst et al. 1981; Casey 1997).

\section{Conclusion}

Based on modal composition, whole rock and mineral chemistry, the Sidi Mohamed peridotites represent residual material of upper mantle origin. Their harzburgitic mineral assemblage and high Fo and $\mathrm{Ni}$ content in olivine, their high $\mathrm{Ni}$ and $\mathrm{Mg}$ whole-rock composition are comparable to features of residual peridotites formed by partial melting of the upper mantle. Their REE contents correspond to those of upper mantle. We suggest that the Sidi Mohamed ultramafic body was derived directly from the upper mantle and tectonically incorporated to the gneiss units of the Edough metamorphic core complex. Their Nb anomaly suggests that during its geodynamic evolution the Sidi Mohamed mantle peridotite was related to a subduction environment.

\section{Acknowledgements}

The authors thank C Físcher, A Musiol and C Günter from Potsdam University as well as D Rhede and O Appelt for their support in sample preparation and analytical laboratories. The first author also thanks DAAD and University of Annaba for financial support. They also thank the reviewers for their helpful comments.

\section{References}

Ahmed Said Y, Leake B E and Rogers G 1993 The petrology, geochemistry and petrogenesis of the Edough igneous rocks Annaba NE Algeria; J. Afr. Earth Sci. 17(1) 111-123.

Ahmed Said Y and Leake B E 1992 The composition and origin of the Kef Lakhal amphibolites and associated amphibolites and olivine-rich enclaves, Edough, Annaba, NE Algeria; Mineral Mag. 56(4) 459-468.

Ahmed Said Y and Leake B E 1997 The petrogenesis of the Edough amphibolites, Annaba, NE Algeria: Two unrelated basic magmas and the lherzolite-harzburgite residue of a possible magma source; Mineral Petrol. 59(3-4) 207-237, doi: 10.1016/0899-5362(93)90027-N.

Arai S 1987 An estimation of the least depleted spinel peridotite on the basis of olivine-spinel mantle array; Neues Jahrb. Ž. Mineral. Monatsh. 8 347-354.

Bhattacharyya C 1971 An evaluation of the chemical distinctions between igneous and metamorphic orthopyroxènes; Am. Mineral. 56 499-506.

Blackman D K, Cann J R, Janssen B and Smith D K 1998 Origin of extensional core complexes: Evidence from the
Mid-Atlantic Ridge at Atlantis fracture zone; J. Geophys. Res. 103 21,315-21,333, doi: 10.1029/98JB01756.

Bossière G, Collomb P and Mahdjoub Y 1976 Sur un gisement de Péridotites découvert dans le massif cristallophyllien de l'Edough Annaba Algérie; C.R. Acad. Sci. 283 885-888.

Bodinier J L and Godard M 2003 Orogenic, ophiolitic and abyssal peridotites; In: Treatise on Geochemistry (ed.) Carlson R W, Mantle and Core, Elsevier, ISBN: 0-08043751-6.

Brey G P and Köhler T 1990 Geothermobarometry in fourphase lherzolites II. New thermobarometers and practical assessment of existing thermobarometers; J. Petrol. 31 1353-1378.

Bruguier O, Hammor D, Bosch D and Caby R 2009 Miocene incorporation of peridotite into the Hercynian basement of the Maghrebides (Edough massif, NE Algeria): Implications for the geodynamic evolution of the Western Mediterranean; Chem. Geol. 261(1-2) 172-184.

Brunnel M, Hammo D, Misserie M, Gleizes G and Bouleton J 1988 Cisaillements synmétamorphiques ave.c transport vers le Nord-Ouest dans le massif cristallin de l'Edough Est Algérien; C.R. Acad. Sci. 306 1039-1045.

Caby R and Hammor D 1992 Le massif cristallin de l'Edough Algérie un 'metamorphic core complex' d'âge Miocène dans les Maghrébides; C.R. Acad. Sci. 314 829-835.

Caby R, Hammor D and Delor C 2001 Metamorphic evolution, partial melting and Miocene exhumation of lower crust in the Edough metamorphic core complex west mediterranean orogen eastern Algeria; Tectonophys. 342 239-273, doi: 10.1016/S0040-1951(01)00166-4.

Campbell I H, Lesher C M, Coad P, Franklin J M, Gorton M P and Thurston P C 1984 Rare earth element mobility in alteration pipes below massive sulfide deposits; Chem. Geol. 45 181-202, doi: 10.1016/0009-2541(84)90036-6.

Cannat M 1993 Emplacement of mantle rocks in the seafloor at mid-ocean ridges; J. Geophys. Res. 98 4163-4172, doi: 10.1029/92JB02221.

Canil D 2004 Mildly incompatible elements in peridotites and the origins of mantle lithosphere; Lithos. $\mathbf{7 7}$ 375-393.

Casey J F 1997 Comparison of major- and trace-element geochemistry of abyssal peridotites and mafic plutonic rocks with basalts from the MARK region of the Mid-Atlantic ridge; Proc. Ocean Drilling Program. Scientific Results, pp. 181-241, doi: 10.2973/odpprocsr1530121997.

Dick H J B and Bullen T 1984 Chromian spinel as a petrogenetic indicator in abyssal and alpine-type peridotites and spatially associated lavas; Contrib. Mineral. Petrol. 86 54-76, doi: 10.1007/BF00373711.

Dick H J B 1989 Abyssal peridotites very low spreading ridge and ocean ridge magmatism; In: Magmatism in Ocean Basins (eds) Saunders A D and Norry M J, Geol. Soc. Spec. Publ. 42 71-106.

Fleet M E, Macrae N D and Hertzberg C T 1977 Partition of nickel between olivine and sulphide: A test for immiscible sulfide liquids; Contrib. Mineral. Petrol. 65 191-197, doi: 10.1007/BF00371059.

Gleizes G, Bouleton J, Bossière G and Collomb P 1988 Données lithologiques et pétrostructurales nouvelles sur le massif cristallophyllien de l'Edough Est Algérien; C.R. Acad. Sci. 306 II 1001-1008.

Gruau G, Bemard-Griffiths J, Lecuyer C, Heuin O, Mace Jr $\mathrm{J}$ and Cannat M 1995 Extreme $\mathrm{Nd}$ isotopic variation in the Trinity ophiolite complex and the role of melt/rock reaction in the oceanic lithosphere; Contrib. Mineral. Petrol. 121 337-350.

Hadj Zobir S 2007 Les formations ultrabasiques-basiques de Sidi Mohamed (Edough, NE Algérien): Caractéristiques 
pétrologiques et géochimiques; Thèse de Doctorat Annaba Algérie, 242p.

Hadj Zobir S 2012 Impact de l'altération sur le bilan chimique des diatexites du massif de l'Edough (Annaba, NE Algérien); Estuds. Geol. 68(2) 203-215, doi: 10.3989/ egeol.40612.158.

Hadj Zobir S, Laouar R and Oberhänsli R 2007 Les métabasites de Sidi Mohamed Edough NE Algérien Caractéristiques pétrographiques minéralogiques et géochimiques; Serv. Géol. Nat. 18 25-41.

Hadj Zobir S and Mocek B 2012 Determination of the source rocks for the diatexites from the Edough Massif (Annaba, NE Algeria); J. Afr. Earth Sci. 69 26-33, doi: 10.1016/j.jafrearsci.2012.04.004.

Hilly J 1962 Etude géologique du massif de l'Edough et du Cap de Fer Est Constantinois; Pub. Serv. Carte Géol Algérie nouvelle Série. 19408.

Kamenentsky V S, Crawford A J and Meffre S 2001 Factors controlling chemistry of magmatic spinel: An empirical study of assiotated olivine Cr-spinel and melt inclusions from primitive rocks; J. Petrol. 42 655-671.

Kornprobst J, Ohnenstetter D and Ohnenstetter M 1981 $\mathrm{Na}$ and $\mathrm{Cr}$ content in clinopyroxenes from peridotites: A possible discriminant between sub-continental and suboceanic mantle; Earth Planet. Sci. Lett. 53 241-254.

Leblanc M and Temagoult A 1989 Chromite pods in a lherzolite massif Collo Algeria: Evidence of oceanic-type mantle rocks along the West Mediterranean Alpine Belt; Lithos 23(3) 153-162, doi: 10.1016/0024-4937(89)90002-9.

Lesher C M, Gibson H L and Campbell I H 1986 Composition-volume changes during hydrothermal alteration of andesite at Buttercup Hill, Noranda district, Quebec; Geochim. Cosmochim. Acta 50 2693-2705, doi: 10.1016/0016-7037(86)90219-X.

McCammon C A, Griffin W L, Shee S R and O'Neill H S C 2001 Oxidation during metasomatism in ultramafic xenoliths from the Wesselton kimberlite, South Africa; Contrib. Mineral. Petrol. 141 287-296.

Michel P J and Bonatti E 1985 Peridotite composition from the North Atlantic regional and tectonic variations and implications for partial melting; Earth Planet. Sci. Lett. 73 91-104, doi: 10.1016/0012-821X(85)90037-8.

Misseri M 1983 Structure et cinématique des péridotites feldspathiques du Cap Bougaroun Algérie; J. Afr. Earth Sci. 6(5) 741-744, doi: 10.1016/0899-5362(87)90009-1.
O'Neill H S C and Palme H 1998 Composition of the silicate Earth: Implications for accretion and core formation; In: The Earth's Mantle: Structure, Composition and Evolution, The Ringwood Volume (ed.) Jackson I, Cambridge University Press, Cambridge, pp. 3-126.

Parkinson I J and Pearce J A 1998 Peridotites from the Izu-Bonin-Mariana Forearc ODPLeg 125: Evidence for mantle melting and melt-mantle interaction in a suprasubduction zone setting; J. Petrol. 39(9) 1577-1618, doi: 10.2973/odpprocsr1251831992.

Rietmeijer F J M 1983 Chemical distinction between igneous and metamorphic orthopyroxenes especially those coexisting with Ca-rich clinopyroxenes: A reevaluation; Mineral. Mag. 47 143-151, doi: 10.1180/ minmag198304734304.

Snow J E and Dick H J B 1995 Pervasive magnesium loss by marine weathering of peridotites; Geochim. Cosmochim. Acta 59 4119-4235, doi: 10.1016/0016-7037(95)00239-V.

SONAREM (Société Nationale De la Recherche Minière) 1980 Projet Edough; Unpublished Data.

Sun S and McDonough W F 1989 Chemical and isotopic systematics of oceanic basalts: Implications for mantle composition and processes; Geol. Soc. London Spec. Publ. 42(1) 313, doi: 10.1144/GSLSP19890420119.

Takahashi E, Uto K and Schilling J G 1987 Primary magma compositions and $\mathrm{Mg} / \mathrm{Fe}$ ratios of their mantle residues along Mid Atlantic Ridge $29 \mathrm{~N}$ to $73 \mathrm{~N}$; Techn. Rep. ISEI, Okayama Univ. Series A9 1-4.

Tucholke B E and Kleinrock M C 1998 Megamullions and mullion structure defining oceanic metamorphic core complexes on the Mid-Atlantic Ridge; J. Geophys. Res. 103 9857-9866, doi: 10.1029/98JB00167.

Zerka M, Cottin J Y, Gregoire M, Lorand J P, Megartsi M and Midoun M 2002 Les xénolites ultramafiques du volcanisme alcalin quaternaire d'Oranie Tell Algérie occidentale témoins d'une lithosphère cisaillée et enrichie; C.R. Acad. Sci. 334(6) 387, doi: 10.1016/S1631-0713(02) 01771-6.

Zhou M F, Robinson P T, Malpas J, Edwards S and Qi L 2005 REE and PGE geochemical constraints on the formation of dunites in the Luobusa ophiolite, southern Tibet; J. Petrol. 46 615-639.

Zuleger E and Erzinger J 1988 Determination of REE and $\mathrm{Y}$ in silicate materials with ICP-AES; Fresenius $Z$ Anal Chemie 332 140-143. 